\title{
LA TEORÍA CRÍTICA ANTE LA CULTURA VISUAL (ACTAS DE UN REENCUENTRO IMAGINARIO ENTRE HORKHEIMER, ADORNO, BENJAMIN Y MARCUSE) ${ }^{1}$
}

\author{
CRITICAL THEORY FACING VISUAL CULTURE \\ (A REPORTED IMAGINARY RE-ENCOUNTER OF HORKHEIMER, \\ ADORNO, BENJAMIN AND MARCUSE)
}

\section{Manuel GONZÁLEZ DE ÁVILA}

Universidad de Salamanca deavila@usal.es

Resumen: El presente artículo propone una síntesis de las posiciones de la Escuela de Francfort ante la cultura visual, proyectándolas hacia el presente y comparándolas con el estado actual de la iconosfera.

1 Este artículo se enmarca dentro de las actividades del grupo de investigación FFI2011-26511. 
Abstract: This paper propounds a synthesis of Frankfurt School's positions about visual culture, projecting them towards the present and comparing them with the current state of the iconosphere.

Palabras clave: Teoría Crítica. Escuela de Francfort. Cultura visual. Iconosfera.

Key Words: Critical Theory. Frankfurt School. Visual Culture. Iconosphere.

Figurémonos, como supuesto de la imaginación científica, una reunión de trabajo en el Instituto de Investigaciones Sociales de Francfort que convocase, tras algunas décadas pasadas en el limbo intelectual, a M. Horkheimer, Th. W. Adorno, W. Benjamin y H. Marcuse para discutir sobre el vigente estado, en plena transmodernidad, de la iconosfera, del universo de imágenes que nos rodea. El ejercicio merece la pena, aunque levantar acta de las discusiones de tales inteligencias quizá resulte una tarea por encima de las capacidades de escritura de un universitario actual.

Tras saludarse con la cordialidad de los viejos camaradas de combate y mirarse con un punto de afectuosa ironía, Horkheimer abriría la sesión recordándoles a los presentes el objetivo de su encuentro: analizar qué ha sido de sus respectivas predicciones sobre la evolución de la cultura y, en particular, sobre el papel que las imágenes iban a desempeñar en los cambios socioculturales. Y aprovecharía para subrayar la vigencia de uno de los principios rectores del trabajo del Instituto: que la crítica teórica ha de ser interna o, como ellos decían, inmanente; esto es, que tiene que abordar su objeto no desde un sistema de valores previos que conduzca a enjuiciarlo sin penetrar en él, sino a partir de la comparación del concepto de ese objeto, de sus posibilidades estructurales, con su realidad efectiva tal y como la sociedad la concreta en cada etapa histórica. Lo cual, aplicado a la iconosfera, supone que el examen de las imágenes debería evitar, cuidadosamente y a la par, la iconoclastia y la iconodulia, tanto el rechazo elitista de lo visual por demasiado accesible como la aquiescencia demagógica ante su persuasiva sugestión. La actitud correcta frente la imagen, para los participantes en nuestra reunión - diría Horkheimer - , consistirá en tomarse en serio la institución social de la imagen contemporánea, y en pedirle cuentas por lo que podría y sin embargo no llega a ser (2000 [1937]), por el perfeccionamiento que estaría a su alcance aportar a una antropología de la mirada. 
Adorno ratificaría estas palabras de Horkheimer, y llamaría la atención sobre la tensa dialéctica del saber que hoy preside la vida de las imágenes, que son simultáneamente lo que mejor nos aproxima al conocimiento, en sus empleos científicos (en medicina, ingeniería, astronomía, geología, botánica, etc., disciplinas a las que la conversión de lo visible, o incluso de lo fisiológicamente invisible, en visual ilimitadamente manipulable ofrece enormes ventajas), y aquello que más nos aleja de él, en sus usos espectaculares (en las industrias del entretenimiento, ese gigantesco caleidoscopio en cuya contemplación se abisma el ocio de las mayorías sociales). Por ejemplo - continúa Adorno - , un mismo medio esencialmente visual, la televisión, acoge, separados por un solo zapping, un documental en el que las técnicas de $h i$ pervisualidad (Català Doménech, 2005), la síntesis digital de imágenes, el grafismo en tres dimensiones y la condensación temporal contribuyen a la ilustración icónica (a nuestro entendimiento de la arquitectura del pasado o de la evolución animal, sin ir más lejos), y una ficción que utiliza los mismos recursos tecnocientíficos, desplegados en suntuosos efectos especiales, para remitologizar el mundo, contraviniendo los esfuerzos de la razón y colonizando seductoramente, por citar a Pasolini, la mente de los espectadores (Adorno y Horkheimer, 2007 [1947]). Incluso con frecuencia un único producto visual se las ingenia para cumplir ambas funciones: el programa sobre medicina que visualiza un implante en el cerebro como si la aguja que lo ejecuta atravesase, sin causar daños, un túnel preexistente en el órgano, ¿está mostrando un procedimiento técnico, o normalizando el imaginario social de la cirugía y haciéndolo más aceptable, menos intimidatorio? Adorno, pensador dialéctico donde los haya, asegura no asustarse ante semejantes contradicciones, antes bien intenta explorar las virtudes de la hipervisualidad - la fabricación de imágenes más reales que lo real mismo - y de su correlato tecnológico, la posvisión - la creación de imágenes potencialmente diferentes de todo lo visto antes - (Català Doménech, 2005) a la hora de romper el predominio secular de la lengua sobre el ojo, es decir la asentada hegemonía cultural de las lenguas naturales sobre las distintas visualidades que los hombres elaboran y difunden. El músico y teórico del arte francfortiano formularía, ante el silencio atento pero un tanto suspicaz de sus colegas, la siguiente propuesta: reparemos en que las neoimágenes actuales, imprevisibles e ingobernables, acaso estén realizando, en los mismos medios de masas igual que a través de los graffiti o del arte digital, lo que para nosotros constituyó uno de los objetivos fundamentales de la Teoría Crítica, esto es, dejar atrás el prejuicio racionalista que pretende someter la sensación al concepto, traduciendo toda experiencia visual a pensamiento proposicio- 
nal; y sujetar lo visible con las redes de lo decible, mutilando con ello la naturaleza, y, de paso, la imaginación. Arrastrado por la pasión utópica de sus propias palabras, Adorno se pregunta si no cabe todavía, en las prácticas de la imagen vernácula, en la costumbre social que el ciudadano medio tiene de fotografiarlo y de filmarlo todo, de convertir su vida en imágenes, algo así como una manifestación espontánea de la subjetividad, una mirada fresca lanzada sobre el mundo de acuerdo con las circunstancias y con las emociones, reunidas en un impagable momento de magia mimética.

En este punto, Marcuse aprobaría con la cabeza y mencionaría que una de las pocas esperanzas puestas por la Escuela en el desarrollo de la tecnología pasaba por que ésta sirviera también, gracias a una inversión dialéctica de su destino inmediatamente económico, para introducir una magnitud estética en la existencia, atemperando la despótica racionalidad instrumental en razón sensible, superadora de la antinomia entre la vida y el arte, y del brutal corte utilitario entre el sujeto contemplador y el objeto contemplado (Marcuse, 2003 [1955]; 1986 [1967]). Y, a fin de defender la lógica que hubo en aquella antigua esperanza, señalaría Marcuse que la misma tecnociencia subjetivamente racionalista responsable de la aparición de satélites capaces de determinar con precisión milimétrica, mediante imágenes, el emplazamiento del objetivo a destruir por los misiles, es la que permite, también mediante imágenes, fomentar nuestra conciencia estética de la belleza del planeta, o nuestra conciencia ecológica de su finitud y su fragilidad. Y advierte que una y otra cosas son resultado de la incesante producción de iconos a la que se entrega la sociedad hiperindustrial, y de los actos de ver asociados a dicha producción, actos que hasta cierto punto implican y complican al observador en lo observado.

Horkheimer, al escuchar a Marcuse, asentiría y rememoraría cómo se impuso a la Teoría Crítica la necesidad de confiar en que la estética empujara a la tecnología a satisfacer finalidades específicamente humanas, puesto que resultaba evidente, ya durante la tercera década del siglo XX, que la civilización tecnológica nada querría saber de la teología ni de la metafísica antiguas, es decir, de las principales fuentes históricas de sentido para el hombre (Horkheimer, 1986 [1947]; Marcuse, Popper y Horkheimer, 1989). Ninguno de nosotros expresó mejor esa esperanza casi escatológica en la fusión potencial de técnica y arte, y en su integración en la existencia cotidiana, que nuestro amigo Walter, dice Horkheimer con una mirada hacia la esquina de la mesa, en la que, haciendo gala de su legendaria discreción y de su reflexivo y nada hostil mutismo, se ha sentado Benjamin. 
Es innegable - intervendría por primera vez el autor de Dirección úni$c a$-: tras la generalización de la fotografía y el advenimiento del cine de vanguardia creímos que, por primera vez en la historia de la humanidad, se habían sentado las bases materiales para una genuina democratización de la cultura, aunque nunca ignoramos el precio que nos veríamos obligados a pagar por ella: la desacralización de la obra de arte, la pérdida irreversible de su autoridad y de su autenticidad, y la trivialización consiguiente de la vivencia estética, transmutada en sucedáneo laico de la religión, en rito social rebajado, en el peor de los casos, a rutina convencional de consumo artístico (Benjamin, 1986 [1936]). Pero nos parecía que lo que el arte podría entonces, aun parcialmente desublimado, enseñar a las mayorías, gracias a sus iluminaciones profanas, era más valioso que la conservación de sus privilegios en tanto instrumento de consagración y símbolo de estatus de las élites económicas, privilegios que habían hecho de él, desde tan lejos como alcanza la memoria humana, el bárbaro y oscuro reverso de la faz luminosa de la cultura (Benjamin, 1986 [1936]). Tal expectativa, que como nos ha recordado Max incluía la de que las artes fotográficas y cinematográficas ayudaran al hombre a asimilar mejor las traumáticas y rapidísimas revoluciones tecnológicas que le aguardaban en otros dominios menos pacificados como los de la economía y la política, se conservó entre algunos de nosotros hasta fechas muy tardías, posteriores a la segunda y definitivamente tecnocrática guerra mundial - añade Benjamin invitando a Marcuse a que retome el hilo de su discurso- .

Así es - convendría este último - : ya dije antes que mi reflexión sobre la tecnología, y más concretamente sobre la tecnociencia, estuvo siempre dirigida por la voluntad de hallar en ella, que nunca iba a involucionar, los elementos de negatividad que le permitieran trascender sus funciones primarias al servicio de la explotación de la naturaleza y del control sobre los hombres. Y no me discutiréis - apostillaría - que si no era en la imagen y en su estética, no había ningún otro lugar del campo cultural en el que depositar nuestras ilusiones. Puesto que todas las prácticas sociales pasaban a depender mayormente de lo visual (la enseñanza, la investigación, la comunicación, el ocio), parecía razonable pensar que sólo en la producción y la recepción de imágenes sería posible reunir por fin el trabajo y el juego, desalienando el primero y dignificando el segundo. Al fin y al cabo, siempre sostuvimos que las sociedades democráticas, como ha dicho Walter, debían socializar no sólo la riqueza, sino también la belleza, trocada de esta suerte en factor de cohesión. Y no podíamos esperar que esa socialización de la belleza, en sociedades que lo son por definición de masas, se produjese a través de la lec- 
tura generalizada del canon literario, o de la escucha atenta del repertorio musical más exigente: el único vehículo disponible para transmitir a las masas la experiencia estética era la imagen, y los medios para fabricar dicho vehículo eran tecnológicos. Ya sabemos que hubo entre nosotros quien predijo que tal puesta a disposición de todo el mundo, y durante todo el tiempo, de la cultura traducida a imágenes llevaría probablemente a la catástrofe, a la disolución de las obras culturales, y a la atrofia del ojo, a la anulación de la mirada (Adorno y Benjamin, 1998) - continúa Marcuse apuntando hacia Adorno, tan concentrado como siempre-, pero otros encontrábamos esa profecía demasiado elitista, y proclive además a complacerse en aquello mismo que lamentaba, en la destrucción del patrimonio cultural a manos de las masas.

No era tan difícil de prever - respondería Adorno con un gesto de cansancio, que fácilmente podría parecer de suficiencia - y de hecho no os hicieron falta a vosotros mismos mis lúgubres presagios para anticiparlo. Tanto Walter como tú lo dejasteis escrito, una vez pasado vuestro entusiasmo inicial por cuanto sonara a aprendizaje perceptivo y a sublimación de la sensibilidad visual. Walter sospechó que la conversión casi automática del conocimiento y del arte en imágenes ilimitadamente accesibles instauraría una pseudocultura ecuménica, vacía de sentido y repleta de ilusiones, de ido$l a$; y tú, Herbert, acabaste por renunciar a tu utopía tecno-erótico-estética y por denunciar que, en el fondo, no había diferencia entre esa infraestructura tecnológica que esperabas doblegar para que ayudara al embellecimiento de la vida, y la más resistente de las superestructuras ideológicas (Marcuse, 1986 [1967]). Incluso llegaste más lejos que yo mismo en la falta de fe, y le retiraste casi toda confianza a la estética y a la imagen (Marcuse, 2007 [1978]), mientras que quien te habla escribía una teoría estética y conservaba la posibilidad de la imagen como instrumento de una mímesis no pervertida, de un diálogo reconciliado y de igual al igual entre el hombre y la naturaleza (Adorno, 1992 [1969]).

Verdad verdadera - concedería Marcuse-, no sólo me desdije de mis ilusiones sobre las consecuencias benéficas que una «amplificación tecnológica» del arte tendría, sino que puse radicalmente en cuestión la dignidad misma de las imágenes artísticas como portadoras de una promesa social. Con el llamado «progreso» de la sociedad de consumo, se me fue apareciendo cada vez más claramente que la decoración integral de la vida de las gentes propuesto por el continuo flujo de las imágenes que las arropan y seducen, lo que algún investigador actual ha llamado la «transestesia generalizada» inducida por la iconosfera (Baudrillard, 2006), era a la par la confir- 
mación y la compensación de su absoluta falta de perspectivas políticas. Quedarse en sus casas gobernando sus pantallas de ordenador, manipulando sus cámaras digitales, haciendo trabajar sus DVD portátiles, volcando las fotos hechas con sus teléfonos móviles, conectando sus escáneres, por mucho que presente una dimensión estética, no deja de ser una conducta privada, con finalidades estrictamente subjetivas, y despojada de toda eficacia histórica. Así quiso siempre el pensamiento burgués que fuera el arte, y así ha conseguido que sean las prácticas pseudoartísticas, tecnológicas, de las mayorías sociales (Marcuse, 2007 [1978]).

Pues sí - ratificaría Benjamin, removiéndose un poco en su silla-, ambos acertáis, el mundo está hoy recubierto por una espesa aleación de arte, ciencia y técnica, y si bien esa aleación ha conservado bajo su manto protector algunos de los ideales sucesivos de la Ilustración y del Romanticismo europeos (la cultura para todos, lo bello al alcance de quien lo merezca), se diría que lo ha hecho transformándolos en caricaturas de sí mismos. Yo creí percibir la deformación de la conciencia estética en subconciencia estésica ya desde mi trabajo sobre los Pasajes. Me pareció que, bajo el reino universal de la mercancía, que se extendía por las ciudades al ritmo al que se implantaban los centros de la «gran distribución comercial», las obras culturales y artísticas, y en especial las imágenes de estas últimas, se convertían en un eterno retorno obsesivo de lo mismo, presentado como novedad e invisibilizado a fuerza de hacerse visiblemente visual sobre decenas de soportes diferentes. ¿Queda alguien, en efecto, para mirar una catedral gótica, para observar un cuadro de Van Gogh o incluso para ver una secuencia de Eisenstein; alquien que pueda aún contemplarlos, como dijimos antes, con lo que ese verbo significa de compromiso sensible y cognoscitivo con lo contemplado? En realidad, no se trata sólo de la pérdida de su aura, como yo avisé, sino de la destrucción de su misma trama material objetiva: las obras de arte reproducidas ad infinitum son ya poco más que la excusa para que la tecnología opere sobre ellas sus apabullantes trucos, para que les cambie el tamaño, la estructura, la disposición, el color; el pasado del arte sirve como coartada para un proceso de autoconocimiento tecnológico, en el que las máquinas de engendrar imágenes exhiben sus poderes sobre los cadáveres de lo que un día fueron obras artísticas vivas y orgánicas, atravesadas por el soplo del espíri$\mathrm{tu}^{2}$. Nosotros llamamos, a los primeros síntomas de esa patología cultural,

El lector interesado encontrará un desarrollo, explicación y actualización de esta tesis en González de Ávila (2010: 273-275). 
«modernos», y no todos ellos los juzgamos perjudiciales. Hoy los teóricos de la cultura los denominan «pos», «hiper»o «transmodernos», pero ya hemos pasado lo suficiente como para concluir que la fantasmagoría y el simulacro han ganado la partida, al menos como dominantes culturales, al arte de la imagen, e incluso a la imagen del arte. Pensad por un momento en los conciertos y en las obras de teatro que, siguiendo el modelo de los mítines políticos y de los acontecimientos sociales, se duplican en pantallas gigantescas, al mismo tiempo y en el mismo lugar en el que están, precisamente, sucediendo: sin su doble icónico e hiperbólico, que lo suplanta y cambia su percepción natural por otra tecnológica, el arte ya no existe.

Justo - proseguiría Adorno-, quizá debiéramos rebasar el examen prioritariamente estético de la imagen, al modo de Walter, tal y como nos la hemos encontrado al «volver» de nuestro limbo intelectual, y plantearle a la iconosfera una pregunta general, casi inocente: ¿eres aún, en este comienzo del siglo XXI, un espacio habitable por la cultura, por lo que la burguesía esclarecida entendió como cultura durante los tres siglos precedentes? Y, para evitar malentendidos, tened en cuenta que nosotros no cultivamos la iconoclastia, tan sólo la exigencia: nuestra crítica interna no pretende destruir las imágenes contemporáneas, sino reclamar de ellas que se justifiquen según la razón, que cumplan sus promesas y que le devuelvan a la historia de la mirada humana algo de lo que han recibido en herencia de los tiempos anteriores. Ni Herbert, ni Walter ni yo mismo, por no hablar de Max, que siempre fue el más equilibrado de los cuatro, somos tan rudimentarios como para no percatarnos de que, en la incontenible marea icónica que anega el mundo, sobrenadan algunas - incluso muchas - maravillas, a veces relacionadas con eso calificado de «hiper»y de «posvisual», maravillas que logran aferrarse hasta a soportes tan resbaladizos como el cine o la televisión. El problema es que llegan envueltas en oleadas de residuos de la entera historia de la representación, arbitrariamente combinados por las estrategias de los diseñadores de modas visuales, y por los caprichos del consumo masivo (Adorno y Horkheimer, 2007 [1947]). ¿Quién, salvo un marginal instruido, una «conciencia infeliz» - según decía Hegel-, está ahora en condiciones de ir a buscar un filme de A. Kiarostami o de K. Ki-Duk en las estanterías de la filmoteca universal, rebosantes de subproductos a los que los mismos críticos cinematográficos ensalzan como si se tratase de obras de cultura, cuando tan sólo lo son de la industria del ocio, de la «diversión», como diría Pascal? ¿O quién reunirá el valor - intelectual, y también ético - necesario para sentarse a ver en televisión una puesta en escena, claro está que subvencionada, de Shakespeare, pudiendo, con un gesto del telemando, mirar un desfile de 
modelos, un telefilme sádica e infantilmente gore, o uno de esos reality shows que dispensan el consuelo de comprobar que siempre hay alguien más feo e indecoroso, más moralmente degradado que uno mismo? Porque la condición insoslayable para poder ver culturalmente, Freud nos lo enseñó, es reprimir la pulsión escópica primaria, y el voyeurismo secundario, de nuestro inconsciente, que atizan sin tregua las multinacionales del entretenimiento, mal llamadas en tiempos por nosotros «de la cultura».

Tienes razón, querido Theodor - es de nuevo Benjamin quien habla -, y a pesar de todo buscamos invariablemente, tú y yo, redimir como podíamos los horrores pseudoculturales, quizá porque nuestro severo moralismo un tanto mesiánico nos conducía a buscar, en el horizonte fragmentado de la cultura de masas, aquellas imágenes que pudieran expresar todavía el deseo de salvar el mundo de las apariencias, de anclar su deriva en una imagen fiable y en una confianza en la imagen. Nos sentíamos demasiado filósofos como para olvidar que la tarea de la filosofía, incluso la de la Teoría Crítica, siempre consistió en liberar la idea original del fenómeno histórico que la encarnaba, a la vez que la desvirtuaba (Benjamin, 1990 [1928]). Fuimos, si nos aplicamos la misma lente histórica que aplicábamos a los demás, los últimos representantes, es verdad que un poco díscolos, del idealismo alemán. Pero no parecía haber forma de lograr esa conciliación del hecho y de la idea, ni tampoco de la imagen y de sus posibilidades. En el mundo que se anunciaba, y que ahora ya se ha encarnado, la experiencia perceptiva estaría hecha de choques bruscos e inasimilables, de intensidades variables y aleatorias. El ciudadano ordinario se halla expuesto, cada día, a varios miles de las que llamamos imágenes tecnológicas (televisión, cine, publicidad estática, interfaces informáticas, etc.). Cuando uno se mueve en esas cifras, la pérdida de la experiencia visual, por paradójico que parezca, ya se ha consumado: la vivencia de la imagen es hoy instantánea, irreflexiva; no hay tiempo para entenderla, para evaluarla - un científico de los de ahora diría «para procesarla»-, de modo que no cabe sino incorporarla a nuestras rutinas perceptivas casi sin pasarla por el filtro de la inteligencia. Basta, para comprenderme, con recapacitar en que en la jerarquía de las prácticas de representación artística la pintura, con sus exigencias de profundidad y de lentitud, ha sido sustituida hace mucho por las imágenes tecnológicas, por la fotoimagen, la videoimagen o las imágenes de síntesis. Estas mismas tecnologías de la visión, fuera del campo artístico, elaboran imágenes-estímulo que simulan la realidad y saturan la comunicación de emociones; se las puede, y de hecho es lo habitual, recibir distraídamente, como pensando en otra cosa, sin concederles más importancia que a cualquier otro elemento de un entorno co- 
nocido y previsible. Lo cual no les impide, antes al contrario, alcanzar, cuando les conviene a sus productores, cotas de una violencia visual difícilmente soportables; porque, como muy bien supo ver Herbert, la agresividad socialmente inducida es uno de los motores fundamentales de la economía capitalista (Marcuse, 1984 [1968]). Y no hablo de violencia sólo en sus contenidos, sino también en su presentación: la heterogeneidad, el fragmentarismo, la discontinuidad y las imparables metamorfosis de las imágenes, rasgos favorecidos por las tecnologías que las engendran (representaos una secuencia de quince minutos de publicidad televisiva para haceros una idea de a qué me estoy refiriendo) pueden desquiciar el aparato sensorial de cualquier incauto, salvo que éste esté ya plenamente condicionado por ese mismo régimen de alimentación visual. De modo que, en cuanto observadores, nos vemos hoy condenados - en fin, lo están quienes viven aquí permanentemente - a oscilar entre la distracción y la obsesión, el descuido y la absorción maníaca en las imágenes (Benjamin, 2007 [1938]). Ni una ni otra actitudes de recepción eran las que nosotros deseábamos para nuestros conciudadanos, a los que pedíamos concentración, rigor en el análisis y distanciamiento racional ante el horizonte perceptivo.

Bueno - corroboraría Marcuse - , esas patologías de la visión, esa incapacidad para ver lo que vale la pena de ser visto y para dejar de ver aquello que nos enajena de la verdadera experiencia visual, sensorial, cognitiva, y finalmente también ética y política, es lo que yo diagnostiqué como una de las consecuencias de la unidimensionalidad de las sociedades tardocapitalistas. Éstas, si bien segregan cantidad, e incluso diversidad - no hay más que sopesar la riqueza de nuestras iconotecas, y la facilidad de su acceso-, destruyen al mismo tiempo la cualidad, porque al haberse superado hace ya mucho los umbrales de saturación de imágenes percibidas, ya no puede sacarse de ellas, como ha dicho Walter, información, y mucho menos pensamiento, pensamiento visual. La iconosfera de este siglo XXI es, para mí, un espacio blandamente totalitario, que permite el reposo y también, según los deseos del cliente, excita a Eros y a Tanatos, el sexo y la violencia, pero del que nadie puede escapar, pues sólo un cínico sostendría que está a nuestro alcance cerrar los ojos, apagar las pantallas, desconectar los aparatos, lo que supondría la muerte social del individuo.

Así es, querido Herbert - confirmaría Adorno-, y tus palabras me retrotraen a cuando, muy joven y sin haber todavía conocido la segunda guerra mundial ni haber escrito Minima Moralia, me figuré que siempre nos quedaría la interioridad como refugio, como claustro de una subjetividad no cosificada desde la que practicar la resistencia (Adorno, 2006 [1933]), en este 
caso contra las imágenes que no hemos elegido, que más bien nos eligen como target, según la jerga de los propagandistas y de los publicitarios. Sin embargo, tú mismo acabas de certificarlo: no hay interioridad que quepa mantener al margen del proceso social, e incluso aunque lográsemos reducir al mínimo nuestro consumo involuntario de prefabricados visuales, eso dejaría aún gravitando sobre nosotros no ya las imágenes sociales, sino la entera sociedad hecha imagen o, en el vocabulario de un colega francés, espectáculo (Débord, 2010 [1967]). Pues espectáculo es ahora el lazo social que los sujetos mantienen entre sí, e incluso consigo mismos: incesante secreción de la imagen que más favorece sus intereses, o que mejor reasegura su siempre insaciable narcisismo. Antes afirmé que la extensión universal de las nuevas tecnologías, de las cámaras analógicas de foto y vídeo, y ahora de las digitales y de las webcams, hubiera podido alentar un florecimiento de la subjetividad de la mirada. Quizá no hubiera hecho en su día esa afirmación de haber tenido en cuenta que los dos principales totalitarismos políticos del siglo XX, el fascista y el comunista, fueron fervientes partidarios de equipar a cada ciudadano con una «cámara personal», locución en la que «personal» quiere decir, en el fondo, lo contrario de «subjetiva». Os pongo un ejemplo: cuando se estudian los archivos icónicos de las llamadas «clases subalternas», las fotos y las películas que hicieron gentes anónimas, lo que se descubre no son puntos de vista inéditos sobre el mundo, visualidades divergentes en sus formas y contenidos respecto de los cánones sociales, sino una inmensa repetición de la doxa visual de cada época (Bourdieu, 2003). De esta suerte, los especialistas en medios de comunicación atestiguan que la pornografía casera o «autopornografía», hoy floreciente por doquier, explota exactamente los mismos tópicos eróticos y las mismas estrategias trilladas de la industria del sexo, que los «aficionados» copian punto por punto, pixel por pixel. Porque ese déficit de subjetividad genuina viene acompañado, como era previsible, del fracaso de los sujetos transmodernos a la hora de liberarse de los patrones más convencionales de presentación y representación del mundo. Aquí también tengo que corregir buena parte de lo que declaré antes, y en el pasado. Hubiese sido razonable esperar que el poder de multiplicar, con unos pocos gestos, el número de sus propuestas visuales, y de modificarlas a voluntad mediante el tratamiento digital, refrescase la pulsión mimética del hombre, y devolviese a éste la posibilidad de aproximarse de nuevo a la naturaleza, de reinventar su relación visual con ella. Y aun cuando en algunos casos sea así, sobre todo en el arte experimental, en la mayoría sucede lo contrario: los esquemas de percepción y de evaluación de lo visible vuelto visual siguen siendo los mismos de siglos atrás, y están 
vinculados a las mismas viejas constelaciones de palabras fósiles y de conceptos cristalizados, es decir que siguen bajo el dominio logocéntrico del pensamiento proposicional que tanto han criticado, inspirados por mí, otros investigadores de la imagen (Arnheim, 1969; Mitchell, 2009). Con todo, lo más inquietante es que, cuando se consigue efectivamente dejar atrás esos consabidos esquemas, normalmente no por voluntad de innovación, sino como resultado de la velocidad y de la aleatoriedad de las tecnoimágenes, descubrimos, demasiado tarde, que el control verbal sobre la imagen resulta intelectivamente menos dañino que su completo descontrol sensorial y perceptivo. En efecto, las nuevas formas de mímesis icónica engendradas por la tecnología adhieren el cuerpo biológico de los espectadores al cuerpo tecnológico de las imágenes, soldándolos en una unidad imaginaria a la que cierto investigador ha llamado una «prótesis simbólica» (Bettetini, 1984), una simulación fantasmática de la vivencia corporal en la que hoy están hundidos los consumidores de holografías, de videojuegos interactivos, de realidades virtuales y aumentadas. Todos esos soportes aspiran a producir una sinestesia global, una polisensorialidad definitiva y arrebatadora, y, cuando la alcancen, la perversión de la mímesis y la sustitución de la experiencia directa por la experiencia inducida, diseñada para los hombres en los laboratorios de las industrias del entretenimiento, se habrá consumado. Claro que, no olvidemos nuestra exigencia de crítica interna ni de pensamiento dialéctico, esa misma «prótesis simbólica» es la que permite a los militares, a los aviadores y a los bomberos entrenarse sin dañar la naturaleza, a los cirujanos practicar sin riesgos para sus pacientes, a los técnicos mejorar la seguridad de los medios de transporte sin recurrir a pruebas con especialistas, etc. ¿Tendremos que defender, contra lo que escribieron Herbert y Foucault sobre el poder biotecnológico (Marcuse, 2005 [1964]; Foucault, 1992), que las tecnologías son neutras, y que es el uso que se hace de ellas lo que las justifica o las incrimina moralmente? Porque ninguno de nosotros nos creemos del todo eso es por lo que se precisaría hoy, más que nunca, una crítica de la imagen, antes que una filosofía o una ciencia de la imagen. Las filosofías de la imagen han abundado desde Platón, pues toda escuela filosófica se enfrenta al problema de la percepción, es decir al juego complementario y contradictorio entre el ser y el parecer, y de la posición gnoseológica que se adopte ante tal problema se deriva naturalmente una determinada concepción de las imágenes. En cuanto a la teoría científica de las imágenes, la harán sin duda, entre otros, los especialistas en neurociencias. Pero lo que más falta hace es que los intelectuales, y quienes disponen de un acceso autorizado al discurso público - Adorno no parece ya dispuesto a detener la exposición de 
su programa - , participen en la elaboración crítica de una ecología de la visión, de una decisión racional sobre el régimen visual al que están sometidos los ciudadanos de nuestras democracias. Ya sé que esto atenta contra la política neoliberal hegemónica: ahora bien, el que haya instituciones de socialización y de educación primarias tampoco es ni podría ser liberal, y nadie, salvo algunos utopistas irresponsables, discute su necesidad.

Amigo Theodor - preguntaría entonces Marcuse, siempre atento a las virtuales derivas autoritarias del despotismo filosófico - ¿ ¿y en qué podría consistir semejante labor de vigilancia pública de un universo perceptivo, el de las imágenes técnicas, que justamente acabamos de definir como inmanejable, ingobernable?

Bueno - respondería Adorno-, yo no estoy en condiciones de decretar de qué modo debería organizarse el sistema público de salud de la imagen, tendré que contentarme con refrescar otro de los principios que guiaron las aproximaciones de la Teoría Crítica a las obras culturales, en mi opinión todavía válido. Nosotros siempre creímos, sobre todo Walter y yo, que el pensamiento podía concentrarse en sus objetos, sumergirse en ellos, incluso en los más aparentemente modestos, hasta obligarles a revelar la razón de su existencia social, y a confesar la totalidad de sus implicaciones estéticas, éticas y políticas. «Micrología», llamamos a ese procedimiento que tanto nos enseñó sobre las mutaciones de la Modernidad, simplemente a partir del estudio de cosas como la manía del coleccionismo, los horóscopos publicados en la prensa o las cancioncillas de jazz radiadas por las emisoras norteamericanas. ¿Y por qué no supeditar ahora el flujo icónico a esa misma mirada atenta, llevándole la contraria a la creencia trivial de que las imágenes actuales son un entretenimiento pasajero, de que en el fondo nada nos dicen y a nada nos obligan, porque unas imágenes borran a otras sin dejarnos ni siquiera una huella en la memoria?

Vaya, Theodor - diría Horkheimer - por una parte de eso ya se ocupan algunas disciplinas vigentes, como la semiótica o el análisis del discurso, y por otra puedes estar seguro de que en las Facultades de Comunicación, donde se enseña publicidad, los profesores invitan a sus alumnos a tomarse en serio las prerrogativas y atribuciones de las imágenes. Aunque es cierto que lo hacen para que las vendan mejor, y no con el ánimo de que desactiven su potencial dañino. Además, ya sabes que yo no comparto tu confianza un tanto idealista en que basta discurrir para descubrir, en que la filosofía es apta por sí sola para provocar una revelación del ser de lo pensado. A día de hoy, la Teoría Crítica no puede prescindir de las ciencias y de sus enseñanzas. Por 
muy pujante que sea un espíritu dialéctico, hay en las imágenes algo más que significados cognoscibles, también están sus funciones sociales, y de ésas sólo la sociología y las ciencias de la comunicación son capaces de darnos cuenta. Por ejemplo, para romper otro prejuicio similar al que tú mencionabas, el de que las imágenes ya no tienen un origen concreto, tal es su abundancia y su ubicuidad, es preciso echar mano de los archivos de dichas ciencias: allí se demuestra que, en realidad, todas las imágenes proceden de una fuente determinable, que disponen de redes de transmisión preferentes, y que apelan a públicos segmentados, sobre los cuales ejercen distintos tipos de efectos. Yo creo que la Teoría Crítica dejaba en un plano demasiado secundario tales datos «externos», a pesar de que casi todos nosotros acumulamos experiencia en la investigación empírica. Si quisiéramos volver ahora a la carga, deberíamos tener la humildad de retomar la práctica de los cuestionarios, de las estadísticas y del trabajo de campo.

Mi buen Max - replicaría Adorno con un punto de burla cariñosa en la voz-, eso ya lo hicimos durante nuestra etapa en USA, y sabes tan bien como yo que, por muy oportunos que resulten los datos, por sí solos no podrán jamás desvelarte la verdad de las imágenes: es la conciencia la que ha de interpretarlas, trazando el mapa de sus relaciones significativas, que con frecuencia no son exactamente empíricas y escapan a toda observación material. Y a ti, que escribiste conmigo la Dialéctica de la Ilustración, no hará falta que te explique que las ciencias sociales, a las que prestas más crédito que yo, pertenecen, al menos en parte, a la razón instrumental contra la que ambos nos alzamos, y que con frecuencia son tributarias de la misma tecnocracia que emplea las imágenes para su gobierno de masas. Entendámonos, no es que yo rechace obtusamente las ciencias sociales, es que la autocrítica radical de la razón a la que quisimos contribuir exige no disimular los límites de unas ciencias que son manifestación fundamental de la razón (Adorno, 1992 [1966]; Honneth, 2005) - Walter Benjamin asentiría levemente a las palabras de Adorno, aunque sin añadir nada más - . Al fin y al cabo - continúa el filósofo y compositor - ¿qué otra cosa puede hacer la Teoría Crítica, qué otro objetivo cabe asignarle, si no es defender la capacidad de la razón para superar sus propias restricciones, y para recuperarse de sus errores más íntimos? En el fondo, hoy todo el mundo produce y consume imágenes, y son muchos los que, como hemos dicho, las estudian. ¿Pero cuántos adoptan ante la denominada cultura visual una posición que quepa calificar, sin ruborizarse, de crítica? ¿Para qué porcentaje de ellos el manejo de imágenes, su análisis o su comentario, es algo más que un placer irreflexivo o que una rutina laboral destinada a devengar beneficios económicos o simbólicos? 
Es verdad, Theodor - convendría Horkheimer, ya visiblemente cansado-, nosotros tratamos de evitar que la actividad intelectual se convirtiese, como Weber predijo, en un aspecto más de un mundo definitivamente administrado y burocratizado. E iríamos contra nuestros propios principios si no denunciásemos que en el desplazamiento, como objeto legítimo de ocupación académica, de la cultura lingüística por la visual, y en el estudio neutralizado de ésta, subyace un interés tecnocrático que no responde a los intereses racionales, emancipatorios, de la mayoría. Ésa es justamente la razón de que nos hayamos dado cita aquí, en este costoso retorno desde nuestro olvido filosófico: para sugerir a los investigadores que hay una forma de trabajar con la imagen, y sobre la imagen, sin por ello dimitir de las obligaciones críticas inherentes al estatuto del intelectual. Yo estoy seguro de que en cada generación habrá investigadores que se sentirán en el deber de exigir de las imágenes el respeto por sus propias posibilidades y por la dignidad de quienes las contemplan. Y ahora, si os parece bien, levantemos la sesión y vayamos a tomarnos un café.

\section{REFERENCIAS BIBLIOGRÁFICAS}

ADORNO, Th. W. (1992 [1969]). Teoría estética. Madrid: Taurus.

- (1992 [1966]). Dialéctica negativa. Madrid: Taurus.

- (2006 [1933]). Kierkegaard: construcción de lo estético. Madrid: Akal.

ADORNO, Th. W. y BENJAMIN, W. (1998). Correspondencia (19281940). Madrid: Trotta.

ADORNO, Th. W. y HORKHEIMER, M. (2007 [1947]). Dialéctica de la Ilustración: fragmentos filosóficos. Madrid: Akal.

ARNHEIM, R. (1969). Visual Thinking. Berkeley: California University Press.

BAUDRILLARD, J. (2006). El complot del arte: ilusión y desilusión estéticas. Madrid: Amorrortu.

BENJAMIN, W. (1986 [1936]). Discursos interrumpidos I. Madrid: Taurus.

- (1990 [1928]). El origen del drama barroco alemán. Madrid: Taurus.

- (2007 [1938]). Libro de los pasajes. Madrid: Akal.

BETTETINI, G. (1984). La conversación audiovisual. Madrid: Cátedra. 
BOURDIEU, P. (2003). Un arte medio. Ensayo sobre los usos sociales de la fotografía. Barcelona: Gustavo Gili.

CATALÀ DOMÉNECH, J. M. a (2005). La imagen compleja. Barcelona: Universidad Autónoma de Barcelona.

DÉBORD, G. (2010 [1967]). La sociedad del espectáculo. Valencia: PreTextos.

FOUCAULT, M. (1992). Microfísica del poder. Madrid: Endymión / La Piqueta.

GONZÁLEZ DE ÁVILA, M. (2010). Cultura y razón. Antropología de la literatura y de la imagen. Barcelona: Anthropos.

HONNETH, A. (2005). «Una patología social de la razón. Acerca del legado intelectual de la Teoría Crítica». En La teoría crítica y las tareas actuales de la crítica, G. Leyva (ed.), 444-468. Barcelona: Anthropos.

HORKHEIMER, M. (1986 [1947]). Ocaso. Barcelona: Anthropos.

- (2000 [1937]). Teoría tradicional y teoría crítica. Barcelona: Paidós.

MARCUSE, H. (1984 ([1968]). La agresividad en la sociedad industrial avanzada y otros ensayos. Madrid: Alianza Editorial.

- (1986 [1967]). El final de la utopía. Barcelona: Ariel.

- (2003 [1955]). Eros y civilización. Madrid: Akal.

- (2005 [1964]). El hombre unidimensional: ensayo sobre la ideología de la sociedad industrial avanzada. Barcelona: Ariel.

- (2007 [1978]). La dimensión estética: crítica de la ortodoxia marxista. Madrid: Biblioteca Nueva.

MARCUSE, H., POPPER, K. y HORKHEIMER, M. (1989). A la búsqueda del sentido. Salamanca: Sígueme.

MITCHELL, W. J. T. (2009). Teoría de la imagen. Madrid: Akal.

Recibido el 10 de mayo de 2012.

Aceptado el 30 de septiembre de 2012. 